\title{
Indisciplina na Escola: Uma Análise dos fatores de Influência no interior do Ceará, Brasil
}

\author{
Rui Barreto da Silva ; Osvaldo Arsênio Villalba ${ }^{2}$
}

Resumo: A Indisciplina apresenta-se atualmente como um elemento importante dentro do espaço escolar, uma vez que toda a comunidade escolar, professores, alunos, pais e núcleo gestor percebem a sua presença, colocandoa, muitas vezes como um dos aspectos que dificulta o processo de ensino-aprendizagem. O objetivo foi analisar aspectos relacionados à indisciplina escolar no município de Banabuiú, no interior cearense - Brasil. Trata-se de um estudo de campo, exploratório e descritivo em escolas públicas do município ora pesquisado. A amostra envolveu o núcleo gestor, professores, alunos e pais. O instrumento de coleta de dados constou de um questionário com questões para caracterização da amostra e questões sobre a percepção do construto estudado. Os resultados levaram a crer que os professores e gestores escolares não se reconhecem com uma preparação adequada para lidar com a questão da indisciplina na escola.

Palavras-Chave: Escola; Disciplina; Indisciplina; Construção; desconstrução.

\section{Indiscipline at School: an Analysis of the influence factors in scools of the interior of Ceará, Brazil}

\begin{abstract}
Indiscipline is currently an important element within the school space, since the entire school community, teachers, students, parents and the core manager perceive their presence, placing it often as one of the aspects that hinders the process of teaching and learning. The objective was to analyze aspects related to school indiscipline in the municipality of Banabuiú, in the interior of Ceará/Brazil. This is a field study, exploratory and descriptive in public schools of the municipality investigated. The sample involved the core manager, teachers, students and parents. The data collection instrument consisted of a questionnaire with questions to characterize the sample and questions about the perception of the construct studied. The results lead one to believe that teachers and school administrators do not recognize themselves as adequately prepared to deal with the issue of indiscipline at school.
\end{abstract}

Keywords: School; Discipline; Indiscipline; Construction; deconstruction.

\section{Introdução}

A indisciplina presente em muitas escolas, tem sido apontada por muitos profissionais como um dos fatores que mais dificultam o processo de desenvolvimento das aprendizagens dos alunos. Assim sendo é importante que cada vez mais trabalhos de pesquisa sejam desenvolvidos dentro das escolas, e que os resultados desses trabalhos possam ajudar efetivamente na superação deste problema.

\footnotetext{
${ }^{1}$ Graduação em História pela Universidade Estadual do Ceará. Mestre em Ciências da Educação pela Universidad San Carlos. Paraguay. Professor do Liceu de Banabuiú. Contato: ruim.ce@ hotmail.com;

2 Docente no Programa de Pós-Graduação em Ciências da Ediucação da Universidad San Carlos - PY. Contato: oavillalba@ hotmail.com.
}

583 Id on Line Rev. Mult. Psic. V.12, N. 41, p. 583-612, 2018 - ISSN 1981-1179 Edição eletrônica em http://idonline.emnuvens.com.br/id 
Muitos relacionam a presença da indisciplina na escola a problemas trazidos das relações familiares, outros associam a falta de domínio dos pais na própria criação dos filhos, alguns colocam a culpa nos meios de comunicação, como a televisão e a internet, há ainda quem generalize e diga que tudo é resultado do sistema. Neste sentido, nos indagamos: O que causa a indisciplina? Quem ajuda a construí-la? Ou a reconstruí-la? Que aspectos estão relacionados à sua construção? O que é feito dentro e fora das escolas que contribui para a prevenção ou desconstrução desse fenômeno? O que é viável sugerir para que as escolas superem o problema da indisciplina? As escolas estão preparadas para enfrentar o problema da indisciplina presente em seu meio, conhecendo seus fatores geradores, apontando caminhos para a sua descontrução e consequente reconstrução da disciplina? Na busca de encontrar respostas a essas perguntas e a outras que porventura venham a surgir, na busca de contribuir com as escolas na prevenção e superação deste problema, é que nos dispomos a realizar esta pesquisa, a fazer este trabalho.

O objetivo geral do presente estudo foi analisar os principais fatores percebidos como relacionados à indisciplina escolar. Para isso, foi necessário também: 1) Verificar se os educadores estão preparados para abordar a indisciplina no cotidiano escolar; 2) Perceber como a temática da indisciplina é trabalhada pelos educadores nas escolas públicas do município de Banabuiú - Ceará; 3) Descrever os fatores que influenciam na construção da indisciplina na visão dos gestores escolares, professores e alunos; 4) Propor possíveis soluções para a temática abordada.

\section{O Problema da Indisciplina}

A tarefa a que nos deteremos agora é de buscar conceituar a indisciplina, efetuando isso a partir de leituras feitas e de nossas reflexões a respeito.

O interior das salas de aula de nossas escolas é o locus onde desponta a problemática da indisciplina. De uma das indisciplinas. Por que é preciso indagar: Qual disciplina se deseja? Quem reclama da indisciplina? Mas o que é indisciplina? Responder a essas questões talvez não seja tão consensual já que Rego (1996, p. 84) fala que

O próprio conceito de indisciplina, como toda criação cultural, não é estático, uniforme, nem tampouco universal. Ele se relaciona com um conjunto de valores e expectativas que variam ao longo da história, entre as diferentes culturas e numa mesma sociedade. (...) também no plano individual a palavra indisciplina pode ter diferentes sentidos que dependerão das vivências de cada sujeito e do contexto em que foram aplicadas. (REGO, 1996, p.84) 
Uma das ideias concebidas é a de que indisciplina é um comportamento indesejado, que quando ocorre por parte de alguns alunos, acaba atrapalhando o desenvolvimento do trabalho em sala de aula e provocando prejuízos no processo de ensino aprendizagem dos outros alunos. Ou seja,

\begin{abstract}
A indisciplina - ou problema de disciplina como é denominado por eles - é definida como uma situação na qual as necessidades do grupo (no caso os colegas de sala de aula) e a autoridade (o professor) estão em conflito com as necessidades do indivíduo (o aluno) que faz parte desse grupo, ou seja, é quando uma pessoa se comporta de um modo que satisfaz as suas necessidades e essa conduta impede que o grupo satisfaça as suas. (CURWIN e MENDLER, apud OLIVEIRA, 2009, p. 06)
\end{abstract}

Para estes autores os problemas de indisciplina não se produzem no vazio, ao contrário, eles fazem parte de um sistema social em sua totalidade.

Podemos relacionar à indisciplina também, o não cumprimento, por parte dos alunos, das regras que a escola apresenta.

Neste sentido Garcia apud Silva ( 2002 p. 28) define indisciplina como negação, divergência ou não reprodução, por parte dos alunos, em relação às orientações, expectativas ou oportunidades que a escola apresenta, através de condutas, relacionamentos, modos de socialização, atitudes e desenvolvimento cognitivo demonstrados por eles.

Amado(1999, p.121) confirma e completa a ideia ao dizer

A concretização da indisciplina acontece através da falta de cumprimento das regras que estabelecem, orientam e presidem as condições das atividades em aula, além do desrespeito às normas e valores que fundamentam o convívio entre os colegas e na relação com o professor enquanto pessoa e autoridade. (AMADO, 1999, p. 121)

Um outro conceito por nós encontrado em nossas leituras e que embasou essa pesquisa, também definido por (Amado,1999, p.114) foi que

"A indisciplina escolar enquanto um fenômeno interativo que ocorre no contexto de sala de aula, sendo ele em grande parte, resultante das características específicas desse contexto, isto é, ela é vista como um fenômeno que decorre da própria natureza e complexidade do processo de ensino". (AMADO, 1999, p. 114)

Para Estrela (2002, p.17), "o conceito de indisciplina relaciona-se intimamente com o de disciplina e tende normalmente a ser definido pela sua negação ou privação ou pela desordem proveniente da quebra das regras estabelecidas". Percebemos que a violação das regras é concebida como uma forma de expressão da indisciplina, uma vez que isso gera dificuldades no processo de aprendizagem e traz prejuízo para a relação professor-aluno. 


\section{A Indisciplina na escola}

Como foi falado anteriormente, a sociedade, a família e a escola vivenciam uma séria crise de valores, uma fragilização das relações pessoais, prejudicando a formação geral do indivíduo, que como uma bola de neve, reproduz em um grau mais elevado a crise de valores, os desentendimentos nas relações humanas.

Charlot (2005, p. 18) nos afirma que estamos "em uma sociedade em que o individuo está se tornando cada vez mais livre e o sujeito cada vez mais abandonado”. É claro que numa sociedade com essas características contradiz diretamente as missões específicas da escola. Não pode ser fácil o papel na escola da prevenção da indisciplina. Principalmente quando o que é ensinado não tem muita relação com a vida real do aluno.

Uma das maneiras de como isso se traduz dentro das escolas são as questões indisciplinares, que tanto atormentam professores, gestores escolares, pais de alunos e até mesmo os próprios alunos que se sentem prejudicados por comportamentos prejudiciais de seus pares, pois isso acaba se refletindo nos resultados acadêmicos.

Vasconcelos(1995, p. 227-252,) assim analisa esse contexto,

[...] as questões indisciplinares têm ocupado um espaço cada vez maior no cotidiano escolar no país[...]. As reclamações dos professores, atualmente partindo até mesmo dos professores da pré-escola, é uma tendência que ainda não é generalizada, porém é preocupante e merece nossa reflexão e discussão, uma vez que é causa de repetência, evasão escolar e também constitui consequência de fracasso do planejamento inicial do professor e da escola, o que serve para reforçar a necessidade de aprofundar nessas questões; portanto, torna mais relevante a proposta desta pesquisa (VASCONCELOS, 1995 , p. $227-252$, .

Aquino (1996, p. 47), faz uma reflexão a respeito das responsabilidades das duas principais instituições responsáveis pela educação do ser humano. Ele diz:

[...] A escola e a família são as duas instituições responsáveis pela educação num sentido amplo. O processo educacional depende da articulação desses dois âmbitos institucionais. Um não substitui o outro, devem sim, complementar-se. Se tanto a família como a escola são as principais responsáveis pela formação da criança ou o adolescente, é preciso que haja coerência entre princípios e valores de uma e outra, evitando confrontos entre professores, alunos, família e escola, o que favoreceria a rebeldia e a indisciplina dos alunos (AQUINO, 1996, p. 47).

A disciplina só pode ser construída através de uma tarefa coletiva de trabalho e relações humanas esperadas dentro de uma atividade, pela regulação cooperativa de alunos, passos primordiais 
para a autonomia com liberdade e responsabilidade. É preciso passar da pedagogia da discurso para a pedagogia da ação: a criança só é indisciplinada quando o trabalho não faz sentido para ela.

Para Freire (1998b, p. 46,), a própria prática educativa pode ajudar na parte disciplinar já que a mesma:

[...]deve desenvolver: um caráter formador, propiciar relações, treinar a experiência do ser social que pensa, se comunica, que tem sonhos que tem raiva e que ama. Baseado nessa filosofia, o educador deve dar a devida importância à parte social do aluno, porque é nela que ele vive sua realidade dia-a-dia, é nela que ele desenvolve seus instintos e é a partir dela que a indisciplina poder desabrochar (FREIRE, 1998b, p. 46).

Segundo o que Silva(2010) propõe nos tópicos anteriores a indisciplina como um fenômeno que decorre da natureza e complexidade do processo de ensino, onde estão presentes os comportamentos indesejados, com evidente presença da mesma nas escolas de Banabuiú.

Podemos perceber entre esses "comportamentos indesejados" o confronto entre a vontade de um indivíduo e a necessidade de um grupo e de seu líder. No caso, o desejo de um aluno e necessidade dos outros alunos e de seus professores.

Para que haja um bom desempenho no cumprimento de suas funções, a escola apresenta, estabelece, constrói suas regras, seus regimentos, seus contratos ou códigos de convivência.

Quanto mais conhecimentos tiverem os segmentos escolares, maior possibilidade de se avançar na busca por um melhor espaço de aprendizagens e convivências, com uma menor presença da indisciplina na escola.

\section{Metodologia}

A referida pesquisa, quali-quantitativa, analítica, destritiva e de corte transversal, foi realizada em doze escolas públicas da rede municipal de ensino no Banabuiú, município localizado a $225 \mathrm{~km}$ da capital Fortaleza. A amostra foi composta por vinte e seis gestores escolares, sendo doze diretores administrativos e catorze coordenadores escolares (perfazendo $100 \%$ da população nessa categoria), vinte e sete professores de português e de matemática dos $5^{\text {os }}$ e $9^{\text {os }}$ anos, e os alunos dos referidos anos, tendo como critério os professores de língua portuguesa e de matemática, por possuírem uma maior carga horária em sala de aula, e, por conseguinte, mais tempo com os alunos e com os problemas vivenciados por ambos os segmentos, bem como trinta por cento dos alunos dos quinto e nono ano, o que corresponde a cento e setenta e sete alunos, estes serão escolhidos de modo aleatório. Um total de 
230 (duzentos e trinta) pessoas, distribuídas entre alunos, professores e gestores escolares, em 12 (doze) escolas de ensino fundamental de Banabuiú.

O instrumento de coleta de dados constou de questionários para alunos, professores e gestores escolares, aplicados entre maio de 2014 a maio de 2015.

\section{Resultados e Discussão}

Na sequência, a tabela com o nível de formação dos professores em Banabuiú-CE.

Tabela 1 - Nível de formação dos professores das escolas públicas do município de BanabuiúCeara(1994-2014)

\begin{tabular}{c|c|c|c|c|c|c|c|c}
\hline \multicolumn{8}{c}{ Nível de formação do professores - Banabuiú-Ce } \\
\hline \multirow{2}{*}{ Ano } & \multicolumn{2}{|c|}{ Ensino Fundamental } & \multicolumn{2}{c}{$\begin{array}{c}\text { Ensino Médio } \\
\text { Magistério }\end{array}$} & \multicolumn{2}{c}{ Licenciatura } & \multicolumn{2}{c}{ Total } \\
\cline { 2 - 9 } & \begin{tabular}{c} 
Frequência \\
\cline { 3 - 9 }
\end{tabular} & $\begin{array}{c}\text { Frequência } \\
\text { Relativa }\end{array}$ & $\begin{array}{c}\text { Frequência } \\
\text { Frequência } \\
\text { Relativa }\end{array}$ & Frequência & $\begin{array}{c}\text { Frequência } \\
\text { Relativa }\end{array}$ & Frequência & $\begin{array}{c}\text { Frequência } \\
\text { Relativa }\end{array}$ \\
\hline 1994 & 135 & 98 & 1 & 1 & 2 & 1 & 138 & 100 \\
\hline 1999 & 19 & 15 & 99 & 79 & 7 & 6 & 125 & 100 \\
\hline 2004 & 0 & 0 & 47 & 34 & 91 & 66 & 138 & 100 \\
\hline 2014 & 0 & 0 & 7 & 4 & 184 & 96 & 291 & 100 \\
\hline
\end{tabular}

Fonte: Plano Municipal de Banabuiú(2015-2025); Prefeitura Municipal de Banabuiú-Setor de Pessoal

A falta de habilidades d o professor em lidar com a indisciplina é por vezes, reflexo de uma formação inadequada para lidar com essa situação específica. Silva (2000) acredita na necessidade de uma preparação específica à gestão das situações de indisciplina na formação dos professores.

\section{Discussão dos resultados para o segmento aluno}

Ao perguntarmos aos alunos se eles acreditam que exista a indisciplina na escola onde estudam, tivemos $95 \%$ das respostas positivas, ou seja, responderam que sim, que existe indisciplina e 5\% responderam que não.

O índice apresentado confirma a presença desse fenômeno em nossas escolas, o que nos sugere que realmente precisamos investigar tal fenômeno, buscando conhecer os segmentos indisciplinados, as abordagens feitas, a preparação da comunidade escolar para trabalhar tal tema, bem como os fatores contribuintes. 
Ao perguntarmos se eles percebem a indisciplina por parte de algum segmento da escola encontramos como resposta que $63 \%$ dos respondentes percebem sim o problema, enquanto $37 \%$ não tem essa percepção.

Em caso afirmativo de percepção de indisciplina na escola em outro segmento, aponte o segmento de prevalência dessa indisciplina.

Quanto aos segmentos indisciplinados tivemos $45 \%$ das respostas indicando os professores, seguidos de 19\% de respostas que apontam que os pais também são indisciplinados; 17\% os gestores escolares e $13 \%$ os funcionários.

Vasconcelos(2009, p.93) afirma que "o saber se comportar aplica-se não só ao aluno, mas a todos - portanto, também ao professor, aos funcionários, à equipe de direção, aos pais, etc". Importante torna-se expandir essa ideia, propaga-la na comunidade escolar, discuti-la, buscando a partir dessa ação, uma visão de que todos estão no mesmo barco, nas mesmas condições e que todos devem contribuir para a superação do problema.

Indagados se seus professores abordam a questão da indisciplina na escola onde você estuda, responderam que $77 \%$ dos professores abordam a temática. Mas as respostas também indicam que 18\% abordam parcialmente, enquanto $5 \%$ dizem que seus professores não abordam tal tema. Diante das respostas, temos a visão de que há uma predominância dos professores que abordam o tema.

Sobre se acreditam que seus professores estão preparados para trabalhar a questão da indisciplina na escola onde você estuda, as respostas foram que, $85 \%$ dos alunos afirmaram que os professores estão preparados para trabalhar a questão da indisciplina na escola; $6 \%$ acreditam que não e, $9 \%$ acreditam que seus professores estão parcialmente preparados para essa ação.

Quanto aos fatores internos geradores do fenômeno da indisciplina, enumeraram os seguintes itens:

Tabela 2 - Ordem decrescente dos fatores internos geradores do fenômeno indisciplina na opinião dos alunos

\begin{tabular}{l|c|c}
\hline \multicolumn{1}{c|}{ Categoria } & Frequência & Frequência relativa \\
\hline Ausência do domínio de sala pelos educadores & 59 & 33 \\
\hline Ausência de uma gestão efetiva & 25 & 14 \\
\hline Ausência de um diálogo afetivo e coerente & 24 & 14 \\
\hline Ausência de uma estrutura física adequada & 17 & 10 \\
\hline Ausência de regras claras e objetivas & 18 & 10 \\
\hline Descumprimento do tempo pedagógico & 14 & 8 \\
\hline Ausência de um clima organizacional favorável & 8 & 4 \\
\hline Domínio dos conteúdos do currículo & 7 & 4 \\
\hline Não cumprimento do contrato pedagógico & 5 & 3 \\
\hline \multicolumn{1}{c|}{ Total } & 177 & 100 \\
\hline
\end{tabular}

Fonte: Pesquisa dos autores, 2014 
As resposta indicaram que $33 \%$ do alunos acreditam que o fator interno que mais gera o problema é a ausência de domínio de sala pelos professores, seguido de $14 \%$ de respostas que indicam a ausência de gestão efetiva e a ausência de um diálogo afetivo e coerente como fatores geradores; $10 \%$ dos alunos acreditam que a ausência de regras claras e objetivas são os fatores geradores de indisciplina.

Sobre a questão da ausência de diálogo afetivo e coerente, percebemos aí um viés relacionado à comunicação, o que nos remete ao pensamento de Vasconcelos $(2009$, p.190) quando diz

Uma das grandes causas da indisciplina é a falta de comunicação, que ocorre por múltiplos fatores: desde o professor não abrir espaço para a expressão do aluno até o aluno conseguir verbalizar, seja porque não entende o que está passando, por sentir a pressão do grupo ou porque foi condicionado à passividade. (VASCONCELOS, 2009, p.190)

Quanto aos fatores externos geradores do fenômeno da indisciplina, enumere de 1 a 6 os itens abaixo:

Tabela 3 - Ordem decrescente dos fatores externos geradores do fenômeno indisciplina na opinião dos alunos.

\begin{tabular}{|c|c|c|}
\hline Categoria & Frequência & Frequência relativa \\
\hline Estrutura familiar & 62 & 35 \\
\hline Uso de drogas & 45 & 25 \\
\hline Grupos de influencias & 23 & 13 \\
\hline Descompromisso com os objetivos da escola & 22 & 13 \\
\hline Violência doméstica & 18 & 10 \\
\hline Condições socioeconômicas & 7 & 4 \\
\hline Total & 177 & 100 \\
\hline
\end{tabular}

Fonte: Pesquisa dos autores, 2014

Observe-se que 35\% dos alunos acreditam que a estrutura familiar é um fator externo gerador do fenômeno da indisciplina; $25 \%$ acreditam que o uso de drogas é um fator; $13 \%$ indicam a interferência dos grupos de influência e o descompromisso com os objetivos da escola. Estas duas últimas respostas indicam um possível caminho para os primeiros passos na busca da superação e prevenção do problema. Mas, que trabalho a escola desenvolve para a prevenção ou superação deste problema?

Sobre se a escola desenvolve algum trabalho voltado para a prevenção ou superação do problema da indisciplina, $73 \%$ dos alunos responderam que sim e, $27 \%$ responderam que não.

Sobre quem os alunos acreditam serem os responsáveis pela indisciplina na escola, as respostas estão na tabela a seguir.

Tabela 4 - Opinião dos alunos sobre quem consideram responsáveis pela indisciplina na escola. 


\begin{tabular}{|c|c|c|}
\hline Categoria & Frequência & Frequência relativa \\
\hline Família & 85 & 29 \\
\hline Professores & 78 & 27 \\
\hline Gestores escolares & 77 & 26 \\
\hline Funcionários & 37 & 13 \\
\hline Outros: sociedade, comunidade & 16 & 5 \\
\hline Total & 293 & 100 \\
\hline
\end{tabular}

Fonte: Pesquisa dos autores, 2014

Observe-se que, $29 \%$ dos alunos entrevistados responderam serem as famílias as responsáveis; $27 \%$ acreditam ser os professores; e $26 \%$ apontam para os gestores escolares como os responsáveis pela indisciplina na escola.

Sobre a responsabilidade da família é importante citar Vasconcelos $(2009$, p.208) quando diz

É muito importante que a família assuma as suas responsabilidades específicas na formação dos filhos. Muitas vezes, o vazio deixado pelos pais provoca grandes perdas na formação da criança, além de obrigar a escola a entrar em campos que não são de sua atribuição: ensinar a lavar a mão antes de comer, a apresentar-se às pessoas, amarrar o sapato, escovar os dentes, descascar frutas, desenvolver valores básicos, religiosidade. (VASCONCELOS, 2009, p.208)

As responsabilidades da família e da escola são complementares, mas não são iguais, e é preciso ficar claro qual a diferença pois "Se não explicitarmos as atribuições dos pais na construção da disciplina escolar, podemos ficar esperando coisas que não são da responsabilidade da família". (Vasconcelos, 2009, p.209)

Quanto a acreditarem ser possível para a escola solucionar o problema da indisciplina, 69\% responderam que sim, é possível a escola resolver tal situação. No entanto, $28 \%$ entendem que isso só é possível parcialmente.

Entendemos que ao acreditarem na solução total ou parcial do problema, é possível também que eles se coloquem à disposição para contribuírem para tal fim, e essa foi também uma pergunta feita a eles.

Sobre as contribuições os alunos podem oferecer para solucionar o problema da indisciplina na escola, os alunos responderam conforme a tabela a seguir. 
Tabela 5 - Opinião dos alunos sobre as contribuições que os mesmos podem oferecer para solucionar o problema da indisciplina na escola.

\begin{tabular}{l|c|c}
\hline \multicolumn{1}{c|}{ Categoria } & Frequência & $\begin{array}{c}\text { Frequência } \\
\text { relativa }\end{array}$ \\
\hline Respeitar professores e colegas & 72 & 27 \\
\hline Formular, conhecer e cumprir as regras & 59 & 22 \\
\hline Comportar-se bem & 47 & 17 \\
\hline Dedicar-se aos estudos & 27 & 10 \\
\hline Respeitar a escola & 22 & 8 \\
\hline Ouvir conselhos dos pais/conversar com professores & 17 & 6 \\
\hline Não usar drogas/não ter preconceitos & 13 & 5 \\
\hline Participar dos projetos educativos & 8 & 3 \\
\hline Não desperdiçar comida Total & 5 & 2 \\
\hline
\end{tabular}

Fonte: Pesquisa dos autores, 2014

A maioria dos entrevistados, 27\%, opinou que uma contribuição é a atitude de respeitar professores e colegas; $22 \%$ dos alunos responderam que a maneira de contribuir seria a participação nos processos de formular, conhecer e cumprir as regras; $17 \%$ disseram que podem contribuir comportando-se bem e $10 \%$ dedicando-se aos estudos.

Este último item, dedicar-se aos estudos vai ao encontro de um dos citados fatores externos geradores da fenômeno: o descompromisso com os objetivos da escola, porque se ao dedicar-se aos estudos faz diminuir a incidência do fenômeno, isso aumentaria então o compromisso com os objetivos da escola, enfraquecendo por conseguinte este fator externo.

\section{Discussão dos resultados para o segmento professor}

Indagados se acreditam que existe indisciplina na escola onde trabalham, 96\% acreditam que sim e, $4 \%$ não acreditam na existência do fenômeno.

Sobre a existência de momentos de discussão para tratar sobre a insdisciplina, na opinião de $59 \%$ dos professores existem na escola, discussões voltadas para a questão da indisciplina na escola, enquanto 33\% dos mesmos defendem a ideia de que as discussões sobre o tema acontecem apenas de maneira parcial; 8\% não percebem a existência dessas discussões.

Indagados sobre se acreditam estarem preparados para lidar com a questão da indisciplina escola, $78 \%$ responderam que estão parcialmente preparados, enquanto apenas $14 \%$ afirmaram sentirem-se realmente preparados. 
O índice de professores que se autodefinem como parcialmente preparados é significativo e sugere a escola a necessidade de tomar providências para que este quadro seja mudado.

Indagou-se a seguir se os professores já participaram ou participam de algum curso (capacitação) voltado para a temática da indisciplina. Assim, 70\% dos professores afirmaram que não participaram de cursos ou capacitação voltados para o tema em discussão; $22 \%$ participaram parcialmente e apenas $8 \%$ responderam que sim, que participaram de tais cursos.

Percebemos com estas respostam o quanto nossos professores precisam se preparar para abordar tal problemática. Pois, ao fazermos o confronto a pergunta sobre se estão preparados para trabalhar o tema; $14 \%$ responderam estar preparados, mas $70 \%$ afirmam que não participaram de cursos ou capacitações. Daí, começa-se a entender o despreparo desses professores para administrar o problema.

Quanto a percepção dos professores sobre aos fatores internos geradores do fenômeno da indisciplina, enumeraram os seguintes itens:

Tabela 6 - Opinião dos professores quanto aos fatores internos geradores do fenômeno da indisciplina.

\begin{tabular}{l|c|c}
\hline \multicolumn{1}{c|}{ Categoria } & Frequência & $\begin{array}{c}\text { Frequência } \\
\text { relativa }\end{array}$ \\
\hline Ausência de um diálogo afetivo e coerente & 8 & 29 \\
\hline Ausência de regras claras e objetivas & 5 & 19 \\
\hline Ausência do domínio de sala pelos educadores & 4 & 15 \\
\hline Ausência de uma estrutura física adequada & 4 & 15 \\
\hline Não cumprimento do contrato pedagógico & 2 & 7 \\
\hline Ausência de uma gestão efetiva & 2 & 7 \\
\hline Descumprimento do tempo pedagógico & 1 & 4 \\
\hline Domínio dos conteúdos do currículo & 1 & 4 \\
\hline Ausência de um clima organizacional favorável & 0 & 0 \\
\hline \multicolumn{1}{c|}{ Total } & 27 & 100 \\
\hline
\end{tabular}

Fonte: Pesquisa dos autores, 2014

Quando solicitados a enumerar, em uma lista sugestiva de 9 (nove) fatores internos geradores do fenômeno da indisciplina na escola; $29 \%$ dos professores apontaram como primeiro fator gerador, a ausência de diálogo afetivo e coerente; 19\% disseram ser a ausência de regras claras e objetivas, enquanto $15 \%$ indicaram a ausência do domínio de sala pelos professores; outros $15 \%$ falaram da ausência de uma infraestrutura adequada.

Quanto aos fatores externos geradores do fenômeno da indisciplina, enumere em ordem decrescente de importância de 1 a 6 os itens abaixo: 
Tabela 7 - Opinião dos professores quanto aos fatores externos geradores do fenômeno da indisciplina.

\begin{tabular}{l|c|c}
\hline \multicolumn{1}{c|}{ Categoria } & Frequência & Frequência relativa \\
\hline Estrutura familiar com os objetivos da escola & 18 & 67 \\
\hline Descompromisso comenicas & 4 & 15 \\
\hline Condições socioeconômis & 2 & 7 \\
\hline Uso de drogas & 2 & 7 \\
\hline Grupos de influencias & 1 & 4 \\
\hline Violência doméstica Total & 0 & 0 \\
\hline \multicolumn{2}{l|}{} \\
\hline
\end{tabular}

Fonte: Pesquisa dos autores, 2014

Neste caso, $67 \%$ dos professores indicaram como primeiro fator externo a estrutura familiar; seguido de $15 \%$ que responderam ser o descompromisso com os objetivos da escola o principal fator externo causador do fenômeno.

Indagados que foram sobre quem são os responsáveis pela indisciplina na escola, os 33\% dos professores responderam ser a família; $27 \%$ assumiram-se como responsáveis e $20 \%$ apontaram ser os gestores escolares os responsáveis.

Estes dados demonstram que professores e alunos têm um mesmo ponto de vista quanto à questão dos responsáveis pela indisciplina na escola. Mesmo com os dados levemente diferentes, a ordem de responsabilização é a mesma, ou seja, em primeiro a família, em seguida professores, e em terceiro lugar os gestores escolares.

Sobre se acreditma que é possível para a escola solucionar o problema da indisciplina, 59\% responderam que é possível parcialmente, e $41 \%$ acreditam que sim. A partir dessas repostas é importante analisar que trabalho a escola desenvolve para a prevenção ou superação do problema.

Sobre se a escola desenvolve algum trabalho voltado para a prevenção ou superação do problema da indisciplina, 70\% responderam afirmativamente a questão.

O índice é um valor considerável, tornando-se importante conhecer que ações são efetivamente desenvolvidas e se são desenvolvidas, por que não apresentam resultados?

Solicitados a apontarem algumas ações desenvolvidas para controle da indisciplina na escola, as respostas estão na tabela a seguir.

Tabela 8 - Ações desenvolvidas para o controle da indisciplina na escola na visão dos professores.

\begin{tabular}{l|c|c}
\hline \multicolumn{1}{c|}{ Categoria } & Frequência & Freq. relativa \\
\hline $\begin{array}{l}\text { Dialogo com os alunos, família, professores e gestores } \\
\text { escolares }\end{array}$ & 16 & 29 \\
\hline Criação de regras coletivas (comunidade escolar) & 11 & 20 \\
\hline Reunião por turmas, com alunos e pais & 10 & 18 \\
\hline Apresentação e execução do Regimento interno & 8 & 15 \\
\hline Palestras com alunos, pais e professores/visitas domiciliares & 6 & 11 \\
\hline
\end{tabular}




\begin{tabular}{r|c|c}
\hline Campeonatos esportivos & 3 & 5 \\
\hline Uso do crachá para saída do aluno & 1 & 2 \\
\hline Total & 55 & 100 \\
\hline
\end{tabular}

Fonte: Pesquisa dos autores, 2014

Neste sentido, 29\% das respostas indicaram como ações desenvolvidas o diálogo com os alunos, família, professores e gestores escolares; $20 \%$ se referiram à criação de regras coletivas. Com $18 \%$ de indicação ficaram as reuniões por turmas, com alunos e pais. A apresentação e execução do Regimento Interno obtiveram $15 \%$ de indicação.

Sobre quais as ações que podem ser desenvolvidas pela escola para prevenir o problema da indisciplina, os resultados estão na tabela a seguir.

Tabela 9 - Ações que podem ser desenvolvidas pela escola para prevenir o problema da indisciplina na opinião dos professores.

\begin{tabular}{l|c|c}
\multicolumn{1}{c|}{ Categoria } & Frequência & $\begin{array}{c}\text { Frequência } \\
\text { relativa }\end{array}$ \\
\hline Definição e cumprimento de regras claras e objetivas & 12 & 24 \\
\hline Palestras e cursos de capacitação sobre o tema & 11 & 22 \\
\hline Reuniões com pais e alunos & 8 & 16 \\
\hline Diálogo claro e objetivo com alunos, pais e professores & 6 & 12 \\
\hline Desenvolver projetos relacionados ao tema & 4 & 8 \\
\hline Presença dos pais na escola & 3 & 6 \\
\hline Ministrar aulas criativas e cumprir o tempo pedagógico & 2 & 4 \\
\hline Buscar apoio externo, ações sociais e psicológicas & 2 & 4 \\
\hline Disciplinar os segmentos da comunidade escolar & 2 & 4 \\
\hline \multicolumn{1}{|c|}{ Total } & 50 & 100 \\
\hline
\end{tabular}

Fonte: Pesquisa dos autores, 2014

Para prevenir o problema da indisciplina, $24 \%$ das respostas indicaram a definição e cumprimento de regras claras e objetivas; $22 \%$ dos respondentes apontaram palestras e cursos de capacitação sobre o tema, como ações importantes para a prevenção da indisciplina; $16 \%$ defenderam a execução de reuniões com pais e alunos; $12 \%$ apontaram o diálogo claro e objetivo com alunos, pais e professores como uma ação válida.

Os dados acima podem nortear as escolas do município de Banabuiú na busca pela prevenção da indisciplina em seus estabelecimentos. Esta é a opinião dos professores.

Perguntados sobre que ações podem ser desenvolvidas pela escola para desconstruir o problema da indisciplina, os professores responderam conforme a tabela a seguir. 
Tabela 10 - Ações que podem ser desenvolvidas pela escola para descontruir o problema da indisciplina na opinião dos professores.

\begin{tabular}{l|c|c}
\multicolumn{1}{c|}{ Categoria } & Frequência & $\begin{array}{c}\text { Frequência } \\
\text { relativa }\end{array}$ \\
\hline Definição e cumprimento de regras claras e objetivas & 8 & 20 \\
\hline Palestras e formações sobre o tema & 6 & 15 \\
\hline Trabalhar junto com a família e conhecer melhor a vida dos alunos & 5 & 12,5 \\
\hline Diálogo claro e objetivo com alunos, pais e professores & 5 & 12,5 \\
\hline Reuniões com pais e alunos & 4 & 10 \\
\hline Desenvolver projetos relacionados ao tema & 4 & 10 \\
\hline Atividades socioculturais e de entretenimento & 3 & 8 \\
\hline Parceria com conselho tutelar e cumprimento de medidas & 2 & 5 \\
socioeducativas & 2 & 5 \\
\hline Comprometer os alunos com os objetivos da escola & 1 & 2 \\
\hline Ministrar aulas criativas e significativas & 40 & 100 \\
\hline \multicolumn{1}{c|}{ Total } & & \\
\hline
\end{tabular}

Fonte: Pesquisa dos autores, 2014

Observou-se como resposta que: $20 \%$ deles sugeriram a definição e cumprimento de regras claras e objetivas; $16 \%$ das respostas apresentaram a sugestão de fazer palestras e cursos sobre o tema. Com um índice de $12 \%$ ficaram as sugestões de trabalhar junto com a família, conhecendo melhor a vida dos alunos e diálogo claro e objetivo com alunos, pais e professores.

$\mathrm{Na}$ opinião dos professores essas ações que podem ser desenvolvidas pela escola para desconstruir o problema da indisciplina.

\section{Discussão dos resultados para o segmento gestor escolar}

Perguntados sobre a existência de indisciplina na escola onde trabalha, 100\% dos gestores afirmaram que sim, que existe indisciplina nas escolas do município.

Também foram indagados sobre se existem momentos de discussão voltados para trabalhar a questão da indisciplina na escola onde o gestor trabalha. Assim, 65\% dos respondentes afirmaram que sim e $35 \%$ disseram que isso acontece parcialmente.

Sobre se acredita que está preparado para lidar com a questão da indisciplina escolar, apenas $23 \%$ dos gestores escolares afirmaram que estão sim preparados para enfrentar a referida questão. Os outros responderam estarem parcialmente preparados. 
Evidencia-se o quanto é necessário a escola capacitar seus gestores escolares para lidar com o tema indisciplina escolar, já que o índice dos que se acham preparados é bem inferior aos que se acham parcialmente preparados.

Sobre se já participou ou participa de algum curso (capacitação) voltado para a temática da indisciplina, 23\% dos gestores escolares que se acham preparados fica cada vez mais evidente ao percebermos que $65 \%$ dos mesmos não participaram nem participam de cursos nem de capacitações sobre o tema abordado; $8 \%$ participaram ou participam parcialmente e apenas $27 \%$ já participou ou participa de curso ou de capacitação sobre indisciplina na escola.

Os dados deixam clara a necessidade dos gestores escolares de participarem de formações ou capacitações sobre indisciplina escolar para que os mesmos possam desenvolver ações que efetivamente previnam ou solucionem o problema.

Quanto aos fatores internos geradores do fenômeno da indisciplina, enumeraram a seguinte ordem decrescente de importância de 1 a 9 os itens na tabela a seguir:

Tabela 11 - Fatores internos geradores do fenômeno da indisciplina, na opinião dos gestores escolares.

\begin{tabular}{l|c|c}
\multicolumn{1}{c|}{ Categoria } & Frequência & $\begin{array}{c}\text { Frequência } \\
\text { relativa }\end{array}$ \\
\hline Ausência de um diálogo afetivo e coerente & 8 & 31 \\
\hline Ausência de regras claras e objetivas & 5 & 20 \\
\hline Ausência do domínio de sala pelos educadores & 3 & 11 \\
\hline Ausência de um clima organizacional favorável & 3 & 11 \\
\hline Ausência de uma gestão efetiva & 3 & 11 \\
\hline Descumprimento do tempo pedagógico & 2 & 8 \\
\hline Não cumprimento do contrato pedagógico & 1 & 4 \\
\hline Domínio dos conteúdos do currículo & 1 & 4 \\
\hline Ausência de uma estrutura física adequada & 0 & 0 \\
\hline \multicolumn{1}{c|}{ Total } & 26 & 100 \\
\hline
\end{tabular}

Fonte: Pesquisa dos autores, 2014

Os gestores escolares apontaram através do índice de $31 \%$ que o fator que mais gera indisciplina na escola é a "ausência de um diálogo afetivo e coerente". Com índice de $20 \%$ das respostas surge o fator "ausência de regras claras e objetivas".

Podemos perceber que o diálogo ou sua ausência, assim como as regras claras ou sua ausência podem determinar ou não a geração de indisciplina na escola.

Quanto aos fatores externos geradores do fenômeno da indisciplina, enumeraram em ordem decrescente de importância de 1 a 6 os itens da tabela a seguir: 
Tabela 12 - Fatores externos geradores do fenômeno da indisciplina, na opinião dos gestores escolares.

\begin{tabular}{l|c|c}
\hline \multicolumn{1}{c|}{ Categoria } & Frequência & Frequência relativa \\
\hline Estrutura familiar & 17 & 65 \\
\hline Descompromisso com os objetivos da escola & 3 & 11 \\
\hline Violência doméstica & 2 & 8 \\
\hline Uso de drogas & 2 & 8 \\
\hline Condições socioeconômicas & 2 & 8 \\
\hline Grupos de influencias & 0 & 0 \\
\hline \multicolumn{1}{c|}{ Total } & 26 & 100 \\
\hline
\end{tabular}

Fonte: Pesquisa dos autores, 2014

Com maioria considerável de respostas e um índice de $65 \%$ apareceu o fator "estrutura familiar. Em segundo lugar e com apenas $11 \%$ das respostas, aparece o fator "descompromisso com os objetivos da escola. Ou seja, para os gestores escolares o fator externo que mais influencia na geração da indisciplina é a estrutura familiar.

Indagados sobre quem são os responsáveis pela indisciplina na escola, 29\% das respostas dos gestores escolares indicam que os principais responsáveis pela indisciplina na escola são os pais de alunos. Os professores aparecem como responsáveis para 23\% das respostas e os gestores escolares com $21 \%$.

Sobre se acreditam que é possível para a escola solucionar o problema da indisciplina, 54\% responderam que "sim" e 46\% responderam que era "parcialmente" possível.

É claro que para a solução desse problema a escola precisa desenvolver algumas ações para prevenção ou superação do problema. Essas ações já existem? Ou ainda não?

Quanto ao fato da escola desenvolver algum trabalho voltado para a prevenção ou superação do problema da indisciplina, $85 \%$ dos gestores escolares afirmaram que sim, que existem ações sendo desenvolvidas. Apenas $15 \%$ disseram que não existem ações nesse sentido.

Foram também instigados a apontar algumas ações desenvolvidas para controle da indisciplina na escola, dentre as quais, as que estão dispostas na tabela a seguir. 
Tabela 13 - Ações desenvolvidas para o controle da indisciplina na escola na visão dos gestores escolares.

\begin{tabular}{l|c|c}
\multicolumn{1}{c|}{ Categoria } & Frequência & $\begin{array}{c}\text { Frequência } \\
\text { relativa }\end{array}$ \\
\hline Criação de regras coletivas (comunidade escolar) & 15 & 27 \\
\hline Dialogo com os alunos, família e corpo docente & 15 & 27 \\
\hline Reunião e/ou palestras comunidade escolar & 11 & 20 \\
\hline Apresentação e execução do Regimento interno & 6 & 11 \\
\hline Projetos educativos/parcerias/ações direcionadas & 5 & 9 \\
\hline \begin{tabular}{l|c} 
Outros (Visitas domiciliares, Curso de capacitação, Presença da \\
família na escola)
\end{tabular} & 3 & 6 \\
\hline \multicolumn{1}{c|}{ Total } & 55 & 100 \\
\hline
\end{tabular}

Fonte: Pesquisa dos autores, 2014

Nesta questão, 27\% das respostas foram a criação de regras coletivas pela comunidade escolar e também $27 \%$ deles, apontaram para o diálogo com os alunos, família e corpo docente. Reuniões e palestras com a comunidade obtiveram o índice de 20\%. Um índice menor, mas mesmo assim, significativo.

Sobre quais as ações podem ser desenvolvidas pela escola para prevenir o problema da indisciplina, as respostas foram dispostas na tabela a seguir.

Tabela 14 - Ações que podem ser desenvolvidas pela escola para prevenir o problema da indisciplina na opinião dos gestores escolares.

\begin{tabular}{l|c|c}
\hline & Frequência & Freq.relativa \\
\hline Todos cumprirem as regras e acordos de convivência & 13 & 23 \\
\hline Desenvolver projetos para prevenção do problema & 9 & 16 \\
\hline Trabalhar a afetividade e a cooperação entre professor e aluno & 9 & 16 \\
\hline Diálogo com a família sobre o tema & 8 & 14 \\
\hline Estudo do Regimento Interno & 6 & 11 \\
\hline Palestra sobre o tema & 6 & 11 \\
\hline $\begin{array}{l}\text { Outros (Visitas domiciliares, aulas atrativas e significativas, } \\
\text { desenvolver a autonomia do aluno) }\end{array}$ & 5 & 9 \\
\hline \multicolumn{1}{c|}{ Total } & 56 & 100 \\
\hline
\end{tabular}

Fonte: Pesquisa dos autores, 2014

Sobre tais ações, $23 \%$ das respostas dos gestores escolares indicaram a ação "todos cumprirem as regras e acordos de convivência". Empatadas com 16\% das respostas apareceram as ações "desenvolver projetos de prevenção e superação do problema" e "trabalhar a afetividade e a cooperação entre professor e aluno". 
Sobre que ações podem ser desenvolvidas pela escola para desconstruir o problema da indisciplina, as respostas estão discriminadas na tabela a seguir.

Tabela 15 - Ações que podem ser desenvolvidas pela escola para descontruir o problema da indisciplina na opinião dos gestores escolares.

\begin{tabular}{l|c|c}
\hline \multicolumn{1}{c|}{ Categoria } & Frequência & $\begin{array}{c}\text { Frequência } \\
\text { relativa }\end{array}$ \\
\hline $\begin{array}{l}\text { Promover, frequentemente, debate e conscientização junto a } \\
\text { comunidade escolar sobre o tema indisciplina }\end{array}$ & 8 & 20 \\
\hline Implantação de projetos que dê responsabilidades aos alunos & 6 & 15 \\
\hline Estabelecimento e revisão de regras de convivência para todos & 5 & 12,5 \\
\hline Estimular autonomia, incentivar cooperação, conquistar autoridade & 5 & 12,5 \\
\hline Estabelecer parceria escola-família & 4 & 10 \\
\hline Cursos e palestras sobre o tema & 4 & 10 \\
\hline Detectar o que ocasiona a indisciplina & 4 & 10 \\
\hline Apoio dos professores, funcionários e famílias & 2 & 5 \\
\hline $\begin{array}{l}\text { Outros (Convocação dos pais dos alunos indisciplinados, Implantar } \\
\text { equipe multifuncional com psicólogos e psicopedagogos) }\end{array}$ & 2 & 5 \\
\hline \multicolumn{1}{c|}{ Total } & 56 & 100 \\
\hline
\end{tabular}

Fonte: Pesquisa dos autores, 2014

Assim, 20\% das respostas dos gestores escolares apontaram para a ação "promover, frequentemente, debate e conscientização junto à comunidade escolar sobre o tema indisciplina"; outros $16 \%$ das respostas dos gestores escolares apontaram a implantação de projetos que deem responsabilidades aos alunos como uma ação viável para desconstrução da indisciplina. O estabelecimento e revisão das regras de convivência para todos e a estimulação da autonomia dos alunos receberam $12 \%$ das respostas.

\section{Análise comparativa entre as concepções: aluno, professor e gestor escolar}

Acredita que existe indisciplina na escola onde você estuda/trabalha?

Ao responderem a pergunta se acreditam que existe indisciplina na escola onde estudam e trabalham, alunos, professores e gestores escolares apresentaram respostas numericamente aproximadas, isso é evidente ao fazermos a leitura da tabela 38 que mostra 95\%, 96\% e 100\% como respostas positivas dos alunos, professores e gestores escolares, respectivamente. 
Esses dados comprovam, de forma irrefutável, a presença da indisciplina nas escolas públicas municipais de Banabuiú, Estado do Ceará, e nos remete à necessidade de investigar vários fatores como: professores e gestores escolares estão preparados para lidar com tal problemática? Quais os fatores internos e externos geradores da indisciplina na escola? Quais ações já são desenvolvidas na escola para superar o problema? E o que os segmentos propõem para prevenir?

Você acredita que professores e gestores escolares estão preparados para lidar com a questão da indisciplina escolar?

Alunos, professores e gestores escolares foram perguntados se acreditavam que os professores e gestores escolares estavam preparados para lidar com a questão da indisciplina na escola. As respostas demonstram que a visão dos alunos difere consideravelmente das visões de professores e gestores escolares, já que na visão dos primeiros, $85 \%$ dos professores estariam preparados, enquanto para professores e gestores escolares apenas $14 \%$ e $23 \%$, respectivamente acreditam estarem preparados. $78 \%$ dos professores e $46 \%$ dos gestores escolares respondem estar preparados parcialmente.

Se nos reportarmos a tabela 2 sobre a formação de professores e confrontarmos veremos que apesar do avanço no nível de formação dos professores, isso não reflete melhoria no enfrentamento do problema da indisciplina na escola.

Participou ou participa de algum curso (capacitação) voltado para a temática da indisciplina?

O resultado é bem próximo entre os dois segmentos, já que $70 \%$ dos professores e $65 \%$ dos gestores escolares responderam que não. Não participaram ou não participam de tais eventos.

A constatação nos surpreende pois já que apenas $8 \%$ dos professores e $31 \%$ dos gestores escolares, disseram anteriormente não estarem preparados para enfrentar o problema. Então, como se preparam, se um alto índice dos dois segmentos não participaram ou participam de cursos ou capacitação sobre a problemática da indisciplina?

Essas questões nos levam a perceber a necessidade emergente de oportunizar às comunidades escolares esse tipo de curso ou capacitação.

Quanto aos fatores internos geradores do fenômeno da indisciplina, enumere em ordem crescente de importância. 
Gráfico 1 - Ordem decrescente dos fatores internos geradores do fenômeno indisciplina na opinião dos alunos, gestores escolares e professores

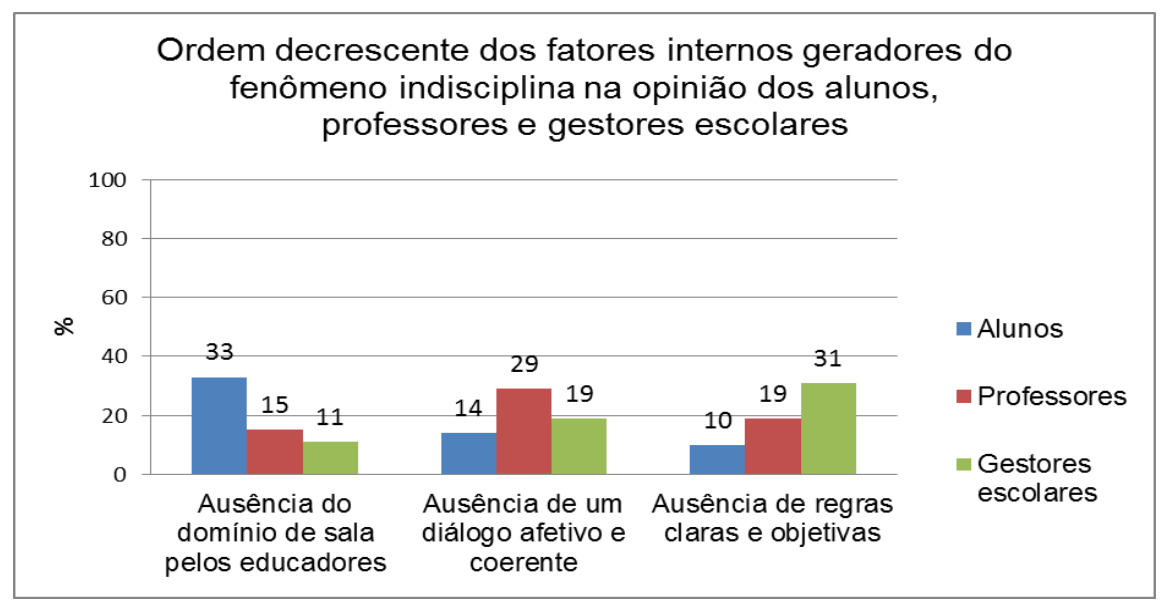

Ao serem solicitados a enumerarem, em uma lista de 9(nove) itens, os fatores internos geradores do fenômeno da indisciplina na escola, alunos, professores e gestores escolares apresentaram os resultados contidos na tabela 41 e gráfico 41 , em que para $33 \%$ das respostas dos alunos apontaram para o fator "Ausência de domínio de sala pelos educadores", 29\% das respostas dos professores apontaram para o fator "Ausência de diálogo afetivo e coerente", enquanto $31 \%$ das respostas dos gestores escolares apontaram para o fator "Ausência de regras claras e objetivas".

Esses três fatores predominaram nas respostas dos segmentos pesquisados, sem no entanto seguirem a mesma ordem de valores. De qualquer forma fica evidente que os três fatores internos são realmente os maiores geradores de indisciplina nas escolas públicas de nosso município.

Sobre a "ausência de regras claras e objetivas" é importante observar o pensamento de Vasconcelos $(2009$, p.228) quando ele afirma que "um procedimento básico é esclarecer muito bem as regras, não deixando pairar dúvidas sobre o que seja a conduta aceitável”. Ele também diz "Uma vez estabelecida, a norma deve ser cumprida por todos: a regra provem de todos, da coletividade, e também se destina a toda a coletividade". Vasconcelos(2009, p.198).

As escolas podem, portanto, tomar essas ideias como parâmetro para definição de suas atitudes.

Quanto aos fatores externos geradores do fenômeno da indisciplina, enumere em ordem decrescente de importância de 1 a 6 . 
Gráfico 2 - Ordem decrescente dos fatores externos geradores do fenômeno indisciplina na opinião dos alunos, professores e gestores escolares

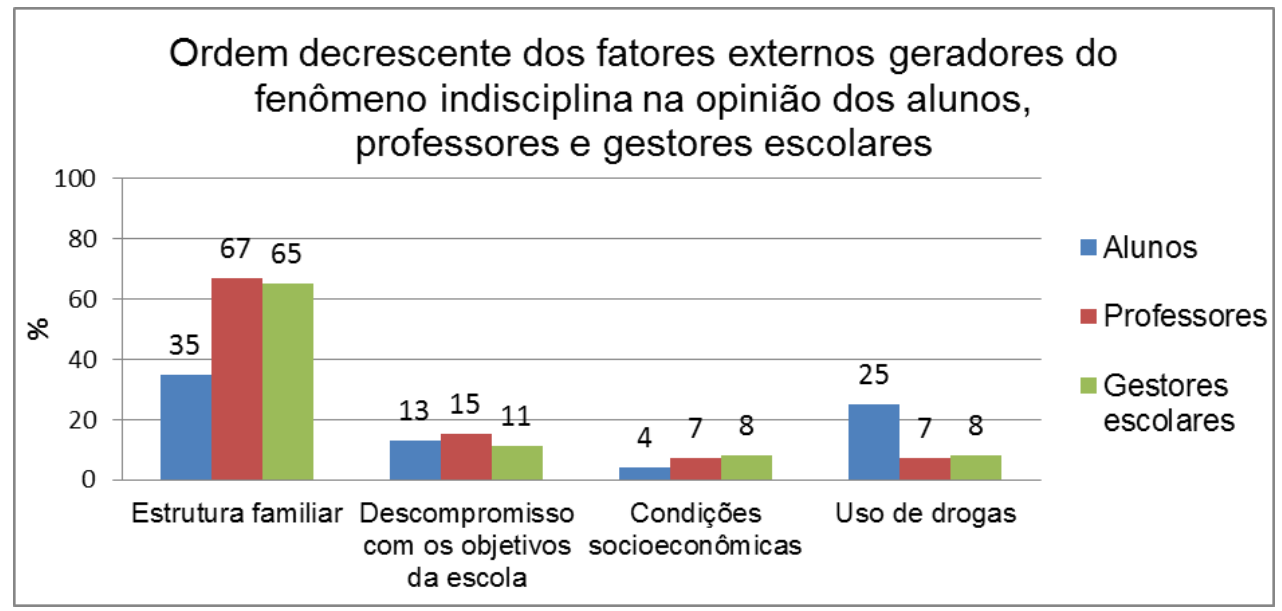

Ao serem solicitados a enumerarem, em uma lista de 6(seis) itens, os fatores externos geradores do fenômeno da indisciplina na escola, alunos, professores e gestores escolares demonstraram a mesma opinião ao indicarem a "Estrutura familiar" como o principal fator externo gerador da indisciplina escolar. Isso se faz notar através dos índices de $35 \%$ das respostas dos alunos, $67 \%$ das respostas dos professores e $65 \%$ das respostas dos professores.

Para 25\% dos alunos, o principal fator a gerar o fenômeno da indisciplina é o "Uso de drogas". Para $13 \%$ dos alunos, $15 \%$ dos professores e $11 \%$ dos gestores escolares, o fator externo que mais contribui para a presença da indisciplina na escola é o "descompromisso com os objetivos da escola". Percebam que em relação a este fator, mesmo os valores não sendo altos, a curiosidade é a aproximação de opiniões entre os segmentos respondentes.

Ao surgirem concomitantemente como fatores externos geradores de indisciplina na escola a "estrutura familiar" e o "descompromisso com os objetivos da escola" concluímos que um fator pode fortalecer o outro, principalmente porque a família tem sempre um papel fundamental nos compromissos escolares de seus constituintes e também nas questões disciplinares. como diz Vasconcelos(2009, p.204),

No processo de construção da disciplina escolar, a família tem importante papel, seja no sentido de buscar conjuntamente alternativas de superação dos problemas, seja porque no lar se encontra, em alguns casos, a origem das primeiras distorções em termos de comportamento e sua postura colabora para a reprodução ou para a transformação de tais atitudes. 
Considerando a relação com a escola, talvez uma das maiores contribuições que a família possa dar no atual momento é a efetiva valorização tanto do estudo quanto da própria escola, enquanto instituição formadora. (VASCONCELOS, 2009, p.204)

Aquino(1996, p.46) propõe a articulação entre estrutura escola e a estrutura familiar. Ele diz

Neste sentido, a estruturação escolar não poderá ser pensada apartada da familiar. Em verdade, são elas as duas instituições responsáveis pelo que se denomina educação num sentido amplo. Só que o processo educacional depende da articulação destes dois âmbitos institucionais que não se justapõem. Antes, são duas dimensões que, na melhor das hipóteses, complementam-se, articulam-se. (AQUINO, 1996, p.46)

Existem momentos de discussão voltados para trabalhar a questão da indisciplina na escola onde você trabalha?

Gráfico 3 - Existência de discussão voltados para trabalhar a questão da indisciplina na escola onde trabalham, por professores e gestores escolares.

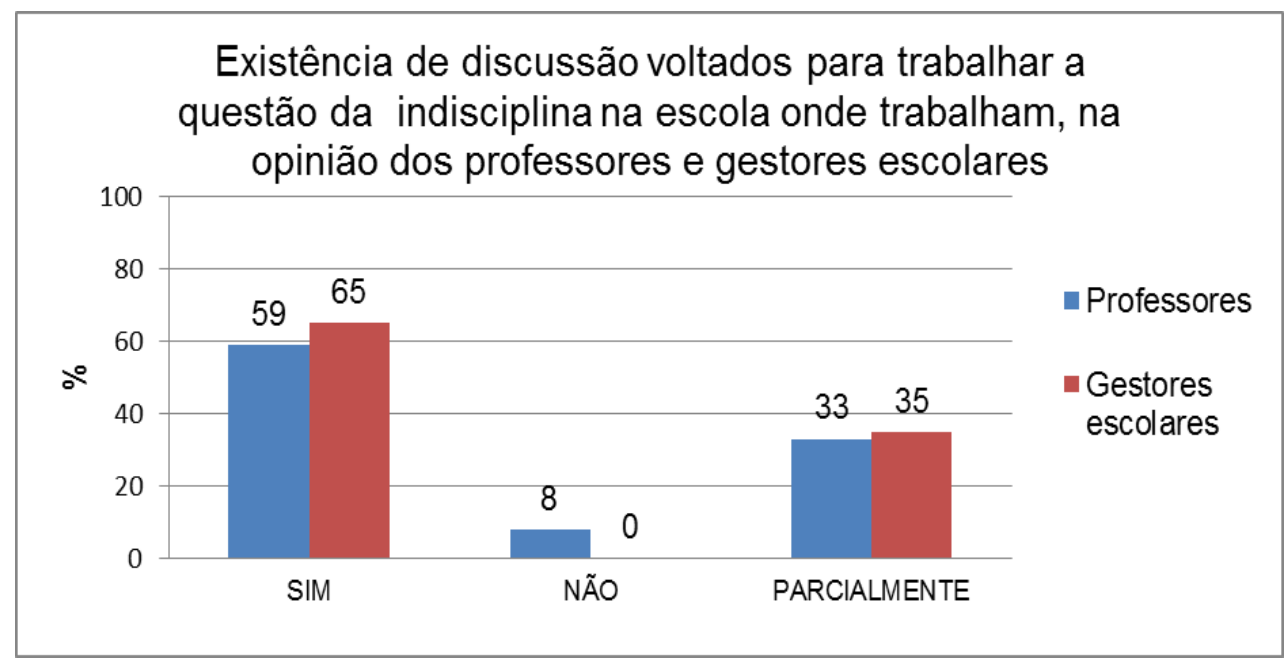

As respostas apresentadas por professores e gestores escolares a essa pergunta são bastante convergentes já que as respostas "sim" aparecem com índices de 59\% e 65\%, enquanto que a resposta "parcialmente" apresentam os índices de 33\% e 35\%.

Acredita que é possível para a escola solucionar o problema da indisciplina? 
Gráfico 4 - Opinião dos alunos, professores e gestores escolares a respeito da crença de ser possível para a escola solucionar o problema da indisciplina.

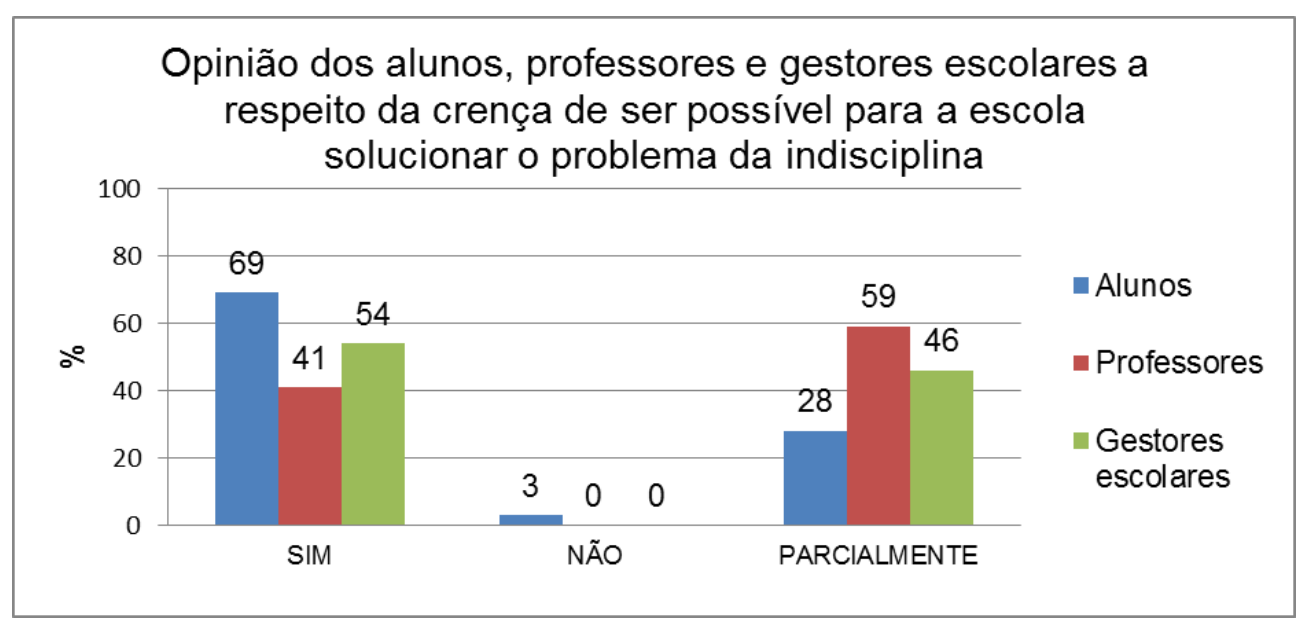

A escola desenvolve algum trabalho voltado para a prevenção ou superação do problema da indisciplina?

Gráfico 5 - Opinião dos alunos, professores e gestores escolares se a escola desenvolve algum trabalho voltado para a prevenção ou superação do problema da indisciplina.

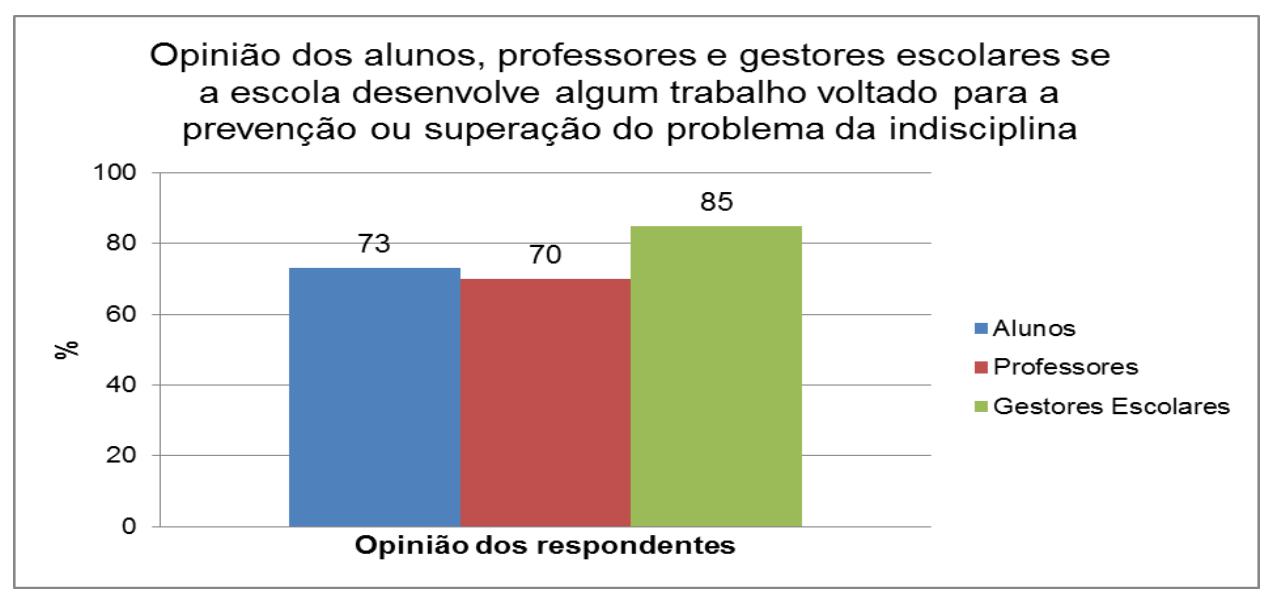

Quando perguntado sobre a existência de trabalhos desenvolvidos na escola voltados para a prevenção ou superação o problema da indisciplina na escola, os segmentos entrevistados tiveram respostas relativamente próximas. $73 \%$ dos alunos, $70 \%$ dos professores e $85 \%$ dos gestores escolares disseram que sim, a escola já desenvolve algum tipo de trabalho com tal finalidade.

É importante, nesse sentido, identificar que trabalho ou ações já são desenvolvidas. É sobre isso que versa o próximo tópico. 
Aponte algumas ações desenvolvidas para controle da indisciplina na escola

Gráfico 6 - Ações desenvolvidas para o controle da indisciplina na escola na visão dos professores e gestores escolares

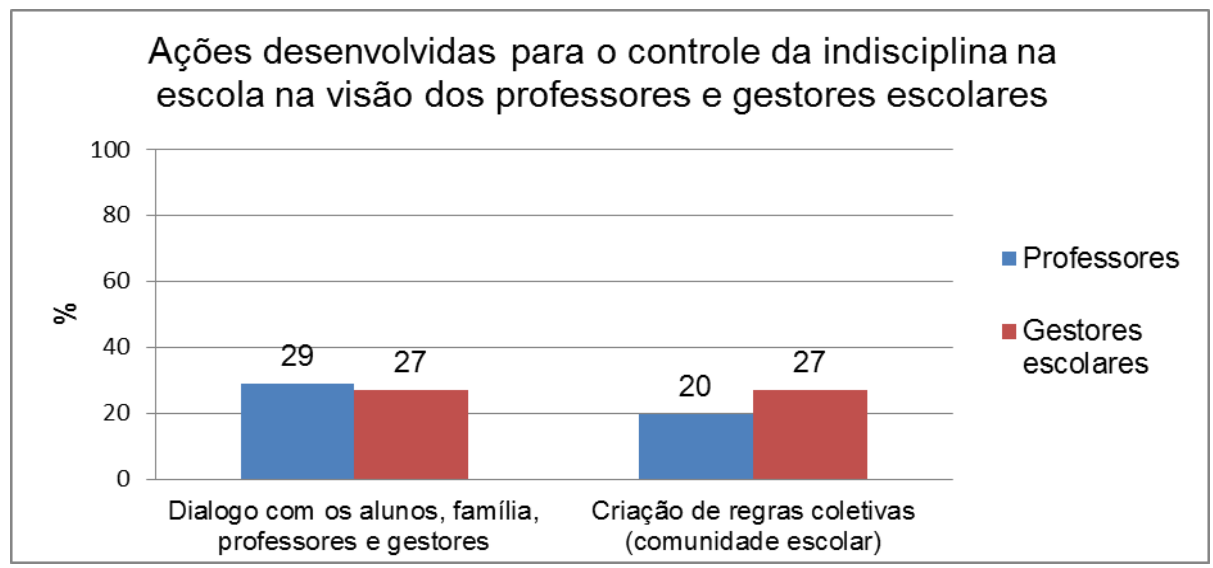

Foi pedido aos professores e gestores escolares para apontarem ações desenvolvidas para o controle da indisciplina na escola na visão dos professores e gestores escolares. Dessa vez, 29\% dos professores e $27 \%$ dos gestores escolares apresentaram como ação desenvolvida pela escola o "diálogo com os alunos, família, professores e gestores escolares", e $20 \%$ dos professores e $27 \%$ dos gestores escolares apontaram a "criação de regras coletivas".

É perceptível que a visão dois segmentos vislumbram as mesmas ações, apesar da tênue diferença apresentada pelos números.

Que ações podem ser desenvolvidas pela escola para prevenir o problema da indisciplina? 
Gráfico 7 - Ações que podem ser desenvolvidas pela escola para prevenir o problema da indisciplina na opinião dos professores

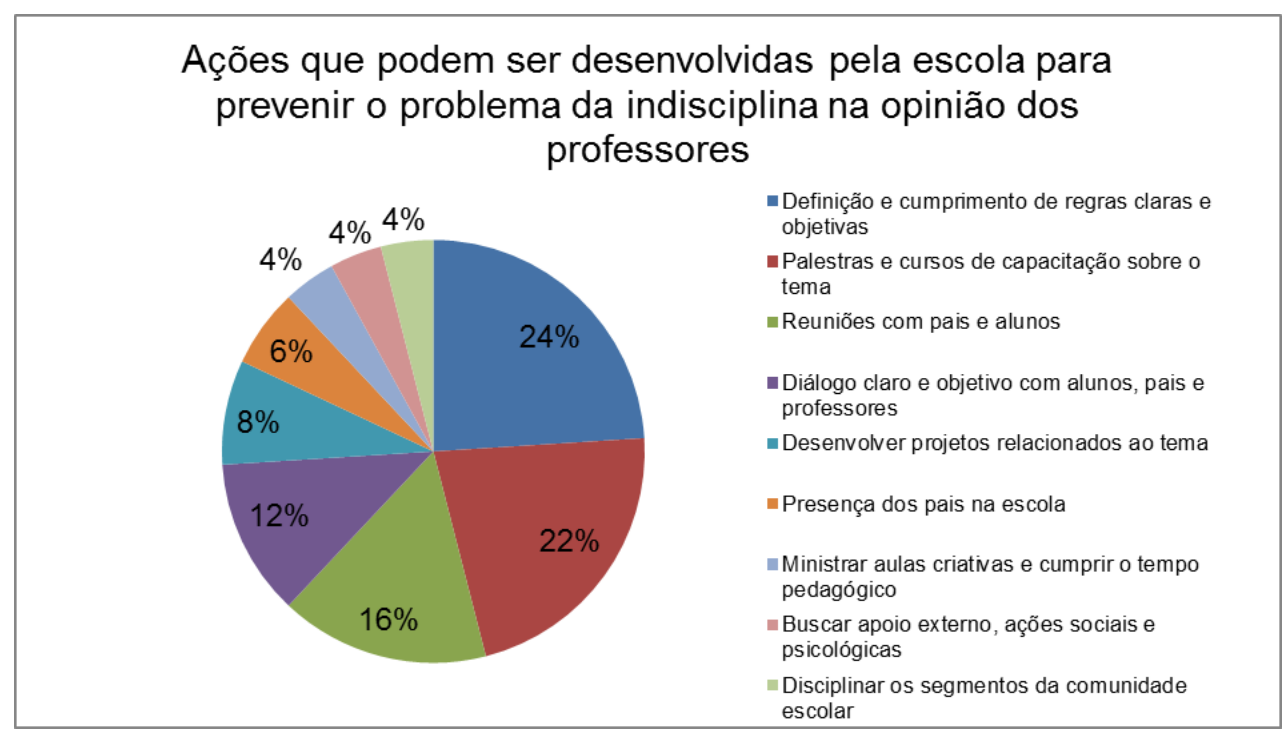

Foi perguntado aos professores que ações poderiam ser desenvolvidas pela escola para prevenir o problema da indisciplina na escola. Ao observarmos as listas apresentadas pelos professores percebemos que $24 \%$ deles sugerem a "definição e cumprimento de regras claras e objetivas". $22 \%$ propõem "palestras e cursos de capacitação sobre o tema". 16\% citam "reuniões com pais e alunos". Diálogo claro e objetivo com alunos, pais e professores foram apontados por $12 \%$ dos respondentes.

Além dessa ações que tiveram maior índice de propostas, achamos importante citar outras propostas como: diálogo claro e objetivo, desenvolvimento de projetos, aulas criativas, cumprimento do tempo pedagógico, disciplinar os segmentos da comunidade escolar que acreditamos também possam contribuir para a prevenção do problema da indisciplina.

Que ações podem ser desenvolvidas pela escola para prevenir o problema da indisciplina? 
Gráfico 8 - Ações que podem ser desenvolvidas pela escola para prevenir o problema da indisciplina na opinião dos gestores escolares

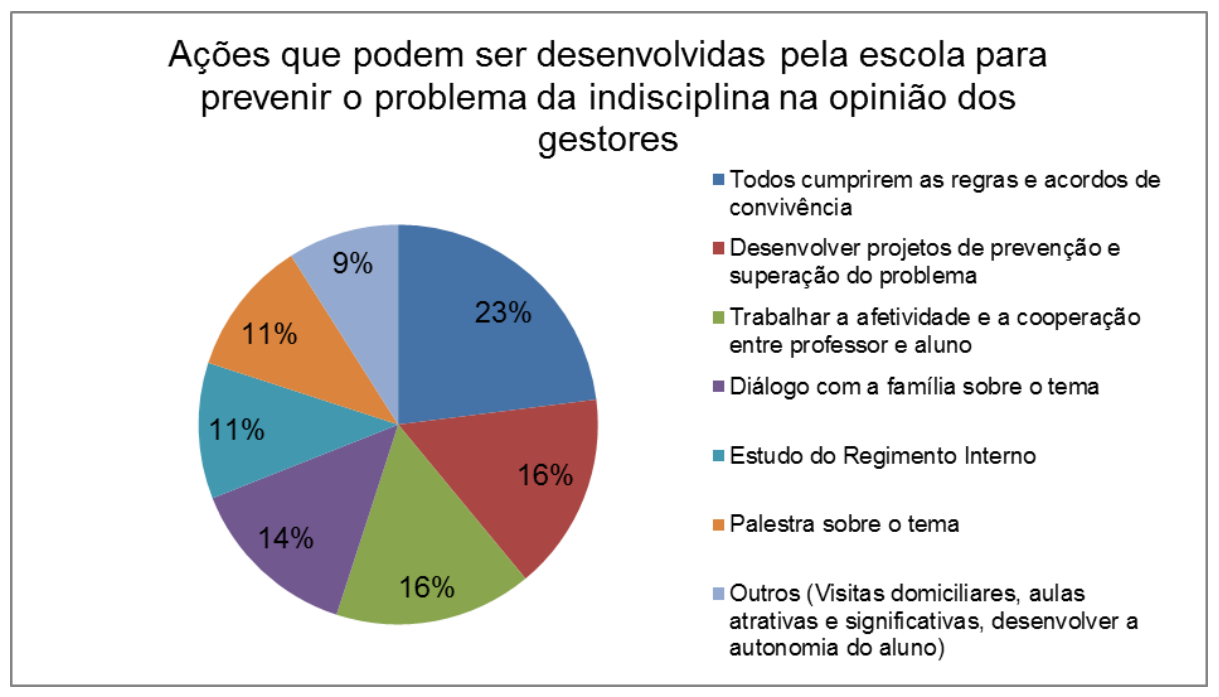

Foi perguntado aos gestores escolares que ações poderiam ser desenvolvidas pela escola para prevenir o problema da indisciplina na escola. Para $23 \%$ dos gestores escolares o caminho é "todos cumprirem as regras e acordos de convivência". "Desenvolver projetos de prevenção e superação do problema" e "Trabalhar a afetividade e a cooperação entre professor e aluno" foram propostas indicadas por $16 \%$ dos gestores escolares entrevistados.

Fica claro que o cumprimento das regras por todos e a valorização da afetividade devem ser trabalhados pela comunidade escolar para que a escola possa prevenir o problema da indisciplina.

Que ações podem ser desenvolvidas pela escola para desconstruir o problema da indisciplina?

Gráfico 9 - Ações que podem ser desenvolvidas pela escola para descontruir o problema da indisciplina na opinião dos professores

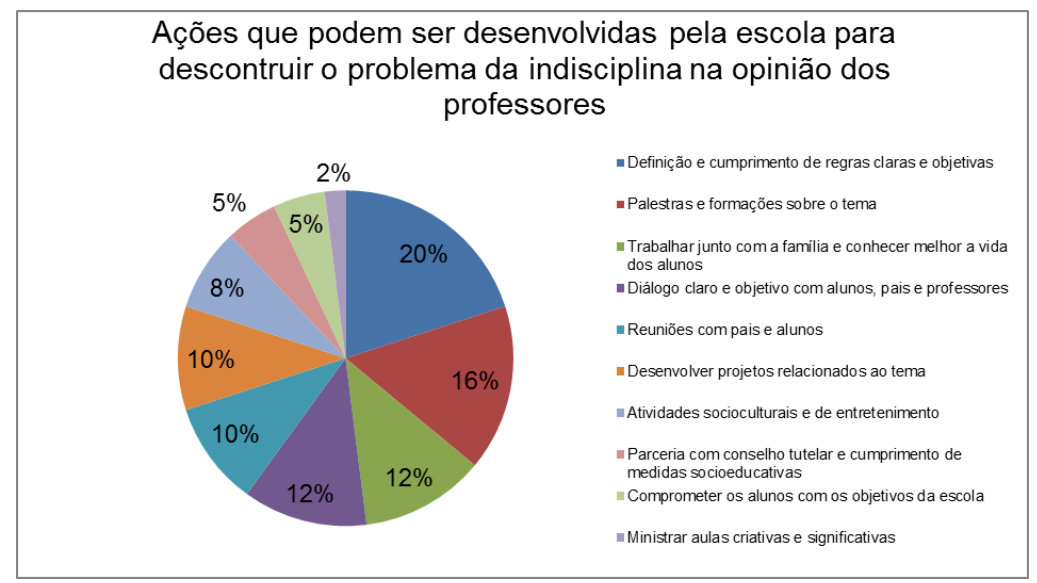


Em relação às ações que podem ser desenvolvidas pela escola para a desconstrução o problema da indisciplina $20 \%$ dos professores sugeriram a definição e o cumprimento de regras claras e objetivas; $16 \%$ sugeriram palestras e formações sobre o tema. Trabalhar junto à família, conhecer melhor o aluno, diálogo claro e objetivo com alunos, pais e professores foram propostas apresentadas por $12 \%$ dos entrevistados.

Reuniões com pais e alunos, desenvolvimento de projetos relacionados ao tema e atividades socioculturais e de entretenimento tiveram $10 \%$ de indicação dos professores como atividades que podem ser desenvolvidas para a desconstrução da indisciplina.

Que ações podem ser desenvolvidas pela escola para desconstruir o problema da indisciplina?

Gráfico 10 - Ações que podem ser desenvolvidas pela escola para descontruir o problema da indisciplina na opinião dos gestores escolares

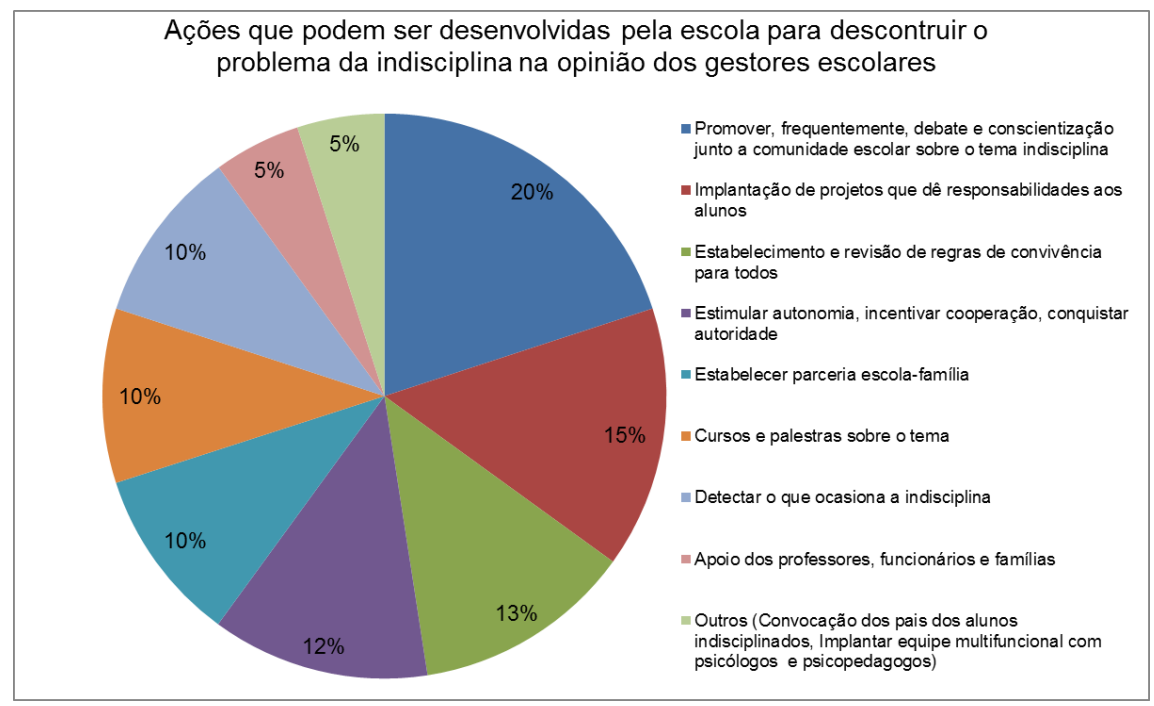

Na opinião de $20 \%$ dos gestores escolares são ações que devem ser desenvolvidas pela escola para desconstrução do fenômeno da indisciplina a promoção frequente de debates e a conscientização junto a comunidade escolar sobre o tema. Para $16 \%$ deles é importante que sejam implantados projetos que deem responsabilidades aos alunos. O estabelecimento e revisão de regras de convivência para todos, a estimulação da autonomia, incentivo à cooperação e a conquista da autoridade foram ações propostas por $12 \%$ dos gestores escolares.

É possível ver através das tabelas 49 e 50 que há a convergência de algumas ideias propostas por professores e gestores escolares. São os casos do cumprimento das regras por todos, a implantação de projetos, a presença da família e a promoção de palestras e debates. 
Para a conclusão deste capítulo utilizaremos o pensamento de Vasconcelos(2009, p. 206) que contempla ações importantes relativas as discussões desenvolvidas.

\begin{abstract}
O ato de indisciplina é um sinal, uma manifestação a ser decodificada pelo professor, que procura ver o que está por trás dela, qual seu sentido. Frequentemente, a indisciplina está perpassada por questões de ordem afetiva; é uma forma de o aluno chamar a atenção sobre si, de pedir que seja resgatado, que seja incluído no movimento vital de onde, por algum motivo, está se sentindo alijado; pode ser desesperado pedido de um sentido para a vida, só que numa linguagem cifrada, de difícil compreensão e até agressiva, o que pode gerar uma postura reativa do professor. O desenvolvimento da autonomia, a internalização de valores, a tomada de decisão e a avaliação dos resultados são fundamentais para todos os campos da vida: escolha profissional, relacionamentos, casamento e até mesmo no delicado, porém cada vez mais presente campo das drogas. (VASCONCELOS, 2009, p. 224 e p. 206)
\end{abstract}

\title{
Considerações Finais
}

Quanto ao primeiro objetivo, que buscou investigar a preparação dos educadores para trabalhar a indisciplina na escola, percebemos que os próprios professores e os gestores escolares assumiram-se como não preparados para tal tarefa. Apenas os alunos acreditaram que seus educadores tivessem essa preparação. É necessário então possibilitar aos educadores tal preparação.

O segundo objetivo procurou saber como a indisciplina é trabalhada na escola pelos educadores de nosso município. O que predominou foram respostas que nos remetem a ações como reuniões, palestras, aplicação de regras e o diálogo.

Quanto aos fatores geradores da indisciplina na escola na visão de alunos, professores e gestores encontramos quatro respostas convergentes: Ausência de diálogo, ausência de regras claras e objetivas, ausência de domínio de sala pelos professores e desestrutura familiar. Quando estabelecemos uma comparação com a análise do segundo objetivo, percebemos que entre as ações desenvolvidas estão regras e diálogos, que no entanto, neste objetivo, essas mesmas ações são colocadas como ausentes. Ou pelo menos que a sua ausência contribui com o problema da indisciplina.

O quarto objetivo sugeria o estabelecimento de possíveis soluções que se concretizaram a partir das sugestões dos respondentes. E as sugestões giraram em torno dos mesmos aspectos, pois os segmentos sugerem que as regras sejam formuladas, aprovadas e cumpridas por todos. Que o diálogo esteja sempre presente entre todos os segmentos da comunidade escolar, diálogo com a família, implantação de projetos envolvendo toda a comunidade escolar, trabalhar a afetividade e a cooperação entre professor e aluno.

Ao nos reportamos à pergunta geral deste projeto, entendemos que a mesma está temporariamente respondida. Professores e gestores escolares não se reconhecem como preparados para 
trabalhar a questão da indisciplina na escola, os fatores que contribuem para a presença da indisciplina na escola estão descritas ao longo da análise dos resultados, assim como as proposições feitas pelos segmentos alunos, professores e gestores escolares. Estas propostas, no entanto, não podem ser, aliás não devem ser colocadas como produto, mas sempre como processo, ou seja, em constante planejamento, ação, reflexão, replanejamento e novamente ação.

\section{Referências}

ALVARENGA, Estelbina Miranda. Metodologia da Investigação Quantitativa e Qualitativa. A4 Diseños: Assunção- Paraguai, 2010.

AMADO, J. S. Indisciplina na aula: regras, tarefas e relação pedagógica. Psicologia, educação e cultura, Lisboa: Colibri, 1999.

ANTUNES, C. É tudo uma questão de contrato. Recife, PE: Ed. Sapiens, 2005.

C. Professor bonzinho= aluno difícil: a questão da indisciplina em sala de aula. Petrópoles, RJ: Vozes, 2002a.

AQUINO, Julio Groppa. A indisciplina e a escola atual. Rev. Fac. Educ., São Paulo, v. 24, n.2, 1998. Disponível em: $<$ http://www.scielo.br/scielo.php? script=sci_arttext\&pid=S0102-25551998000 200011\&lng=pt\&nrm=iso>. Acesso em: 28 Nov 2007.

Julio Groppa. (Org.). Indisciplina na escola: alternativas teóricas e práticas. 8. ed. São Paulo: Summus, 1996.

BRASIL. Lei de diretrizes e bases da educação. Lei n. 9.394, de 20 de dezembro de 1996. Estabelece as diretrizes e bases da educação nacional. Diário Oficial da República Federativa do Brasil, Brasília, 23 dez. 1996.

MEC. Projeto Nordeste. Chamada à ação combatendo o fracasso escolar no Nordeste. Programa de Pesquisa e Operacionalização de Políticas Educacionais. Brasília: Projeto Nordeste, Banco Mundial, Unicef, 1997.

DE LA TAILLE, Y. A indisciplina e o sentimento de vergonha. In: AQUINO, J. G. (Org.). Indisciplina na escola: alternativas teóricas e práticas. 8. ed. São Paulo: Summus, 1996. p. 9-23.

DOURADO, Luiz Fernandes. Progestão : como promover, articular e envolver a ação das pessoas no processo de gestão escolar?, módulo II. Brasília: Consed - Conselho Nacional de Secretários de Educação, 2001.

Edições Loyola, 2003.

ESTRELA, M. T. Relação pedagógica, disciplina e indisciplina na aula. 3. ed. Portugal: Porto, 1992.

FERREIRO, E. A revolução da informática e os processos de leitura/escrita. In: Pátio - Revista Pedagógica, ano 3, nº 9, p. 59-63, maio./jul.1999 
FILHO, Luiz Schettini. Limites e Disciplina numa dimensão afetiva. Recife, PE: Ed. Sapiens, 2005.

FRANCO, Francisco Carlos. A indisciplina na escola e a coordenação pedagógica. In: O coordenador pedagógico e o cotidiano da escola. São Paulo: Edições Loyola, 2003

FREIRE, P. Pedagogia de esperança. 5. ed. Rio de Janeiro: Paz e Terra, 1998b

FREIRE, P.\& ILLICH, Ivan. Diálogo. In: Seminario Invitacion A Concientizar y Desescolarizar: Conversacion permamente, Genebra, 1974. Atas. Buenos Aires, Busqueda-Celadec. 1975, 109 p.

GARCIA, J. Indisciplina na escola. Revista Paranaense de Desenvolvimento, Curitiba, n. 95, p. 101108, jan./abr. 1999.

LOPES, Raimundo Edilberto Moreira. Escola e Família: alianças na formação do cidadão - Assunção: Universidade San Carlos, 2012

LIBÂNEO, J. C. Didática. São Paulo: Cortez, 1990.

OLIVEIRA, Rosimary Lima Guilherme. Reflexões sobre a indisciplina escolar a partir de sua diversidade conceitual. IX Congresso Nacional de Educação. 26 a 29 de outrubro de 2009. PUCPR

PENIN, Sônia Teresinha de Souza. Progestão: como articular a função social da escola com as especifidades e as demandas da comunidade?, módulo I. Brasília: CONSED - Conselho Nacional de Secretários de Educação, 2001.

SANTOS, Claudevone Ferreira dos. A indisciplina no cotidiano escolar. Candombá - Revista Virtual, v. 2, n. 1, p. 14-23, jan - jun 2006. Salvador - Ba

SILVA, Rui Barreto da. (In)disciplina: uma (re)construção. Banabuiú, 2012.

SILVA, S. A. S. Disciplina em aulas de Educação Física. Educación Física y Deportes, Buenos Aires, n. 18 , fev. 2000.

TARDIF, M. Saberes docentes e formação profissional. 9. ed. Petrópolis: Vozes, 2008.

VASCONCELLOS, Celso dos Santos. Disciplina: construção da disciplina consciente e interativa em sala de aula e na escola. São Paulo: Libertad, 1995

C. dos S. Indisciplina e disciplina escolar: Fundamentos para o trabalho docente. São

Paulo: Cortez, 2009.

Como citar este artigo (Formato ABNT):

SILVA, Rui Barreto da; VILALBA, Osvaldo Arsênio. Indisciplina na Escola: Uma Análise dos fatores de Influência no interior do Ceará, Brasil.. Id on Line Rev.Mult. Psic., 2018, vol.12, n.41, p.583-612. ISSN: 1981-1179.

Recebido: 08/05/2018

Aceito 10/07/2018 